\title{
How Different Ownership Structures Perform in Industry 4.0: A Case of Malaysian Manufacturing SMEs
}

\author{
Aamir Iqbal Umrani ${ }^{1 *}$, Satirenjit Kaur Johl ${ }^{2}$ \\ ${ }^{1}$ DHA Suffa University, Pakistan \\ ${ }^{2}$ Universiti Teknologi PETRONAS, Malaysia
}

\begin{abstract}
Small and medium enterprises are vital components for economic growth globally. Similarly, the Malaysian manufacturing SMEs has contributed greatly in developing Malaysia's economy. However, higher failure rate of the Malaysian SMEs is a great concern among researchers and government bodies. Currently, the industry 4.0 has changed the business environment globally. Therefore, this study attempts to investigate the relationship of ownership structures on firm performance with a mediating role of innovation. Baron and Kenny approach of mediation analysis was used on the sample of the Malaysian manufacturing SMEs. The results revealed that, majority SMEs prefer traditional business methods, which causes the higher failure rate in the industry.
\end{abstract}

\section{Introduction}

The term industrial revolution (IR) is a well-known phenomenon in today's competitive word. The industry and research institutions are putting extensive emphasize on identifying the possibilities to fully utilize the concept for better future performance. Currently, the term IR has transformed into IR 4.0, after decades of progressing in the industry. The Term IR 4.0 was first used by the German government for safeguarding the long-term competitiveness of the manufacturing industry (Henning, 2013), by incorporating cyber-physical- system (CPS) in manufacturing (Lasi, Fettke, Kemper, Feld, \& Hoffmann, 2014). The IR 4.0 focuses on establishing self-regulating, intelligent and interconnected industrial value creation (Liao, Deschamps, Loures, \& Ramos, 2017). CPS include smart machines, production facilities, and storage systems, which assist in exchanging information and mutually control each other. Recent literature on IR 4.0 aims at technological developments related to CPS and its organizational implementation. In addition, in the investigation, the technical field current study focuses on the innovation practices by family ownership and foreign ownership to improve the firm performance of the Malaysian manufacturing SMEs. However, the academic literature on IR 4.0 focuses on large firms (Arnold, Kiel, \& Voigt, 2016) and little attention was paid in small and medium enterprises (SMEs) perspective (Schmidt et al., 2015). The SMEs are the roots for financial gains of any country (Umrani, Johl, \& Ibrahim, 2017). These companies are critical in creating sustainable economy (Hogeforster, 2014).

The Malaysian SMEs sector has a huge contribution in countries economy. The Malaysian SME sector contributes $32 \%$ to overall GDP (Umrani, Johl, \& Ibrahim, 2015), and 65\% in the employment sector (SME Corporation Malaysia, 2015). In Malaysia, 93.7\% businesses are SMEs (SME Corporation Malaysia, 2015). In spite of the importance and critical presence of SMEs, the Malaysian SME sector face 60\% failure rate, and 50\% SMEs collapse during their first five years of operations (Chong, 2012).

In today's rapidly developing world and the introduction of IR 4.0, innovation becomes a critical success factor for the businesses. Innovation has a fourfold definition, 1) implementation of new or improved production methods, 2) implementation of new or improved process methods, 3) new marketing methods, and 4) new organizational methods (OECD, 2005). Innovation was found as most critical success factors for the businesses. Similarly, innovation has been identified as vital to take Malaysia out of the middle-income trap to a high-income nation (National SME Development Council, 2012 - 2020). Unfortunately, the innovation level in Malaysian firms is not only low (INSEAD, Organization, \& University, 2017), but it is limited to the foreign-owned firms (Model, 2010). Malaysian SMEs are

*Corresponding Author: umrani.aamir@yahoo.com

() The Authors, published by EDP Sciences. This is an open access article distributed under the terms of the Creative Commons Attribution License 4.0 (http://creativecommons.org/licenses/by/4.0/). 
family concentrated (Umrani et al., 2015). However, it cannot be concluded that Malaysian SMEs are non-innovative but rather very little information is available on the innovativeness of SMEs.

The relationship between family ownership and firm performance has been the center of the investigation in the developed countries (Essen, Oosterhout, \& Carney, 2012), little attention has been paid to the developing countries. However, in the Malaysian context, public listed companies were the core subject of analysis (Haji \& Mubaraq, 2015). Limited researchers have included SMEs in their analyses, Tan, Chong, Lin, and Eze (2009) examined the Information and Communication Technologies (ICT) and the role of personality traits and different other issues in the Malaysian context. On the other hand, the link between foreign ownership, partnership is yet missing.

Therefore, this paper examines the relationship between family ownership, foreign ownership, partnership, innovation and firm performance. The innovation is injected as a mediator in the model to investigate how innovation can improve the firm performance of SMEs having different ownership structures.

\section{Literature review}

Family ownership and its relationship with innovation have been critically discussed in the past studied. Prior researchers investigated that, the ownership concentration depresses innovation (Raoul, Pierluigi, \& Monica, 2012). Italy is one of the countries that represent a perfect example to examine the conflicts of interest among large and minority shareholders and their effect on innovation. Italian corporate sector has concentrated ownership, where individual owners have a huge stack of equity, whereas, the institutional ownership is less diffused compared to the United States. The findings indicated the negative influence of conflicts of interest among large and minority shareholders on innovation.

In contrast, researchers found a positive link between the introduction of new products, service and innovation outcomes and family involvement. The significant justification of those studies is that family firms own distinctive characteristics and resources, which encourage innovation. For instance, family firms choose innovation and learning as their long-term goals (Ashwin, Krishnan, \& George, 2015), their informal knowledge sharing (Zahra, 2010), and stewardship behavior. Consisting of a large sample of 47 countries, Ayyagari, Demirgüç-Kunt, and Maksimovic (2012) proved that family firms produce a higher number of new products compared to the non-family firms.

Innovation is one of the critical success factors for sustainable growth of companies and country as a whole. Foreign investors are believed to be equipped with better technical skills and innovative behavior (AlAzzawi, 2012). It transfers skills, technology diffusion, and access to the wider market (AlAzzawi, 2012). Furthermore, the knowledge flow varies among different industries and sectors; similarly, it ranges from the technological leaders and followers. Despite the importance of foreign ownership, the relationship between foreign ownership and innovation is unclear (Masso, Roolaht, \& Varblane, 2013). The foreign-owned companies have access to the advanced technologies, and they have the advantage of transferring old technology to the domestic firms (Almeida \& Fernandes, 2008). In some cases, foreign-owned firms may limit the knowledge transfer to non-affiliated firms to protect their advantage. Thus, it is not necessary that foreign ownership could improve innovation activities in the host country. The relationship between foreign ownership, innovation, and firm performance has been previously investigated. However, it is still unclear that a foreign firm improves the firm performance. Most of the studies were focused on overall spillover effects of foreign ownership on country's economy (Rjoub, Aga, Abu Alrub, \& Bein, 2017). Moreover, the developed countries and large firms were the center of research of majority prior literature.

Past literature was mostly focused on the relationship between different partnership types and internationalization (D’Angelo, Majocchi, \& Buck, 2016), partner conflicts (Westman \& Thorgren, 2016), external managers, family ownership, (D’Angelo et al., 2016), ownership strategy (Tanganelli \& Schaan, 2011) and corporate governance (Teixeira Latini, Rubens Fontes-Filho, \& L. Chambers, 2014). However, less attention was paid on the relationship between partnership and firm performance (D'Angelo et al., 2016) and innovation (Ughetto, 2010). Thus, the partnership was never been examined with firm performance through innovation in SMEs.

Innovation is considered as an opportunity for entrepreneurial firms to gain higher performance (Schumpeter, 1934). In recent past, researchers found that innovation is critical for the sustainable SME sector (Abdul Halim et al., 2015). On the contrary, few researchers found there was no relationship between innovation and firm performance (Hilmi, Ramayah, Mustapha, \& Pawanchik, 2010). Instead, innovation was considered as context depended (Rosenbusch, Brinckmann, \& Bausch, 2011). Thus, various ownership structures and their BoDs have influenced innovation, either positively or negatively.

Firm performance has been defined as; how a firm uses its resources to sustain in the marketplace (Thompson \& Zang, 2015), achievement of growth and strategic goals (Hult, Hurley, \& Knight, 2004). Firm performance can be further defined as the relationship between the actions taken together with competitive forces, which allow the firm to 
use the internal resources to adjust to the external environment, incorporating the ideas of effectiveness and efficiency. In this regard, firm performance is linked with the overall firm accomplishments due to new or improved measures taken to increase profitability and growth (Gunday, Ulusoy, Kilic, \& Alpkan, 2011). Financial and non-financial methods need to be used to achieve the strategic goals and to measure prolonged success. Firm's innovation capacity may influence the firm performance. Effective innovation can be progressively seen as a significant element to increase the firm performance in different industrial zones (Zahra, 2010), and it may bring the competitive advantage to the firm and assist in sustaining in the marketplace (Jiménez-Jiménez \& Sanz-Valle, 2011).

SMEs are short-term focused, and they cannot identify the advantages and opportunities available to them in the marketplace. Prior literature provided the inconclusive results on SMEs performance. Few authors concluded their analyses with a positive relationship between innovation and firm performance, whereas, some finds no or negative relationship (Heugens, Essen, \& Oosterhout, 2009). Keskin (2006), analyzed that, innovative capabilities of SMEs help to improve their firm performance, whereas Coles, Daniel, and Naveen (2014) find no relationship. Otero- Neira, Lindman, and Fernández (2009) concluded that innovation has the positive impact on firm performance and firms' other performance levels are depending on a variety of innovations developed (Forsman \& Temel, 2011). SMEs works in a niche market by creating a close relationship with their customers. There is mutually dependent and supporting association between innovation and firm performance (North \& Smallbone, 2000). Thus, the literature provided inconclusive results in the relationship between innovation and firm performance. Therefore, following hypotheses are based on the above discussion:

Hypothesis 1. Innovation has a mediating effect on the relationship between family ownership, foreign ownership, partnership, and firm performance.

Hypothesis 1a. Family ownership has a negative impact on innovation.

Hypothesis 1b. Foreign ownership has a positive impact on innovation.

Hypothesis 1c. Partnership has a positive impact on innovation.

Hypothesis 1c. Innovation has a positive relationship with firm performance

\section{Methodology}

This research followed quantitative approach, and the data was collected from 245 Malaysian medium sized manufacturing SMEs. The data was screened and different ownership structures were identified from the sample for regression analysis. In this research, family ownership, foreign ownership, partnership were considered as independent variable, firm performance as a dependent variable and innovation as a mediator variable. The Baron and Kenny (1986) approach was used to analyse the mediating impact of innovation between the relationship between independent and dependent variable. The regression analysis was applied to conclude this study.

\section{Results}

The survey included 245 responses, out of which, 157 (53.6\%) companies were identified as family firms, 88 (30\%) as foreign firms, and $48(16.4 \%)$ partnership firms.

The regression models revealed in Model 1, where only family ownership was used as a predictor, the value of $\mathrm{R}$ $=0.480$ and $\mathrm{R}^{2}=0.239$. This indicates negative correlation coefficient between family ownership and firm performance, which is -0.480 and family ownership explains $23.9 \%$ of the variance in firm performance. However, the inclusion of innovation as a mediator in Model 2 increased the $\mathrm{R}^{2}=0.703$. The results indicated that family ownership explains $23.1 \%$ variance in firm performance, and innovation explains $70.3 \%$. After comparing both models (Model 1 and Model 2), it is clear that the variance of firm performance can be better explained by adding innovation in the model. Similarly, Model 3 shows the value of $\mathrm{R}=.338$ and $\mathrm{R}^{2}=.114$ this indicated a positive correlation between foreign ownership and firm performance. However, the inclusion of innovation shows that the addition of innovation in the model increased the value of $\mathrm{R}=.842$ and $\mathrm{R}^{2} .708$. The findings revealed that the inclusion of innovation explains $70.8 \%$ variance, which is higher than the model without innovation. Finally, the last models investigated the mediating impact of innovation on the relationship between partnership and firm performance. The model 6 show the value of $\mathrm{R}=.241$ and $\mathrm{R}^{2}=.058$ indicated a positive relationship between partnership and firm performance. Whereas, the model 7 included innovation in the model, which revealed that innovation mediates the relationship between partnership and firm performance. The results are presented in table 1 . 
Table 1. Summary of Mediation Models

\begin{tabular}{|c|c|c|c|c|}
\hline Model & $\mathbf{R}$ & $\mathbf{R}^{\mathbf{2}}$ & Adjusted $\mathbf{R}^{\mathbf{2}}$ & Sig. F Change \\
\hline $\mathbf{1}$ & .480 & .239 & .237 & .000 \\
\hline $\mathbf{2}$ & .839 & .703 & .701 & .000 \\
\hline $\mathbf{3}$ & .338 & .114 & .111 & .000 \\
\hline $\mathbf{4}$ & .842 & .708 & .706 & .000 \\
\hline
\end{tabular}

\section{Discussion and Conclusion}

This study explores the mediating effect of innovation on the relationship between family ownership and firm performance of Malaysian manufacturing SMEs. The findings revealed that family ownership has a negative relationship between innovation and firm performance. However, innovation plays a critical role as a mediator to enhance the firm performance of Malaysian manufacturing SMEs. Based on the findings, some insights and recommendations are offered to scholars, practitioners, and policymakers.

Based on the Baron and Kenny (1986) approach, innovation was found completely mediating the relationship between family ownership and firm performance. Therefore, it can be concluded that the innovation is a critical success factor for family firms to get higher firm performance and to sustain in the marketplace in the long run. Similarly, the policymakers are advised to encourage foreign firms, which have spillover effects on the industry.

Furthermore, in relation with IR 4.0, innovation is a critical tool for SMEs to stay in the market to meet diverse customer demand and meet the contemporary production methods. The IR 4.0 require SMEs to understand the essence and importance of innovation for sustainable growth in marketplace. Results shows that the Malaysian SMEs are more inclined toward traditional production methods that has adverse impact on sustainability and their survival in the industry. The literature has shown that the Malaysian SMEs has a great failure and low survival rate (Chong, 2012). Therefore, innovation is critical for the Malaysian SMEs like their counterparts in developed countries.

\section{References}

Abdul Halim, H., Ahmad, N. H., Ramayah, T., Hanifah, H., Taghizadeh, S. K., \& Mohamad, M. N. (2015). Towards an Innovation Culture: Enhancing Innovative Performance of Malaysian SMEs. Academic Journal of Interdisciplinary Studies, 4(2).

AlAzzawi, S. (2012). Innovation, productivity and foreign direct investment-induced R\&D spillovers. The Journal of International Trade \& Economic Development, 21(5), 615-653. doi: 10.1080/09638199.2010.513056

Almeida, R., \& Fernandes, A. M. (2008). Openness and technological innovations in developing countries: evidence from firm-level surveys. The Journal of Development Studies, 44(5), 701-727.

Arnold, C., Kiel, D., \& Voigt, K.-I. (2016). How the industrial internet of things changes business models in different manufacturing industries. International Journal of Innovation Management, 20(08), 1640015.

Ashwin, A. S., Krishnan, R. T., \& George, R. (2015). Family firms in India: family involvement, innovation and agency and stewardship behaviors. Asia Pacific Journal of Management, 32(4), 869-900. doi: 10.1007/s10490-0159440-1

Ayyagari, M., Demirgüç-Kunt, A., \& Maksimovic, V. (2012). Firm Innovation in Emerging Markets: The Role of Finance, Governance, and Competition. Journal of Financial and Quantitative Analysis, 46(06), 1545-1580. doi: doi:10.1017/S0022109011000378

Baron, R. M., \& Kenny, D. A. (1986). The moderator-mediator variable distinction in social psychological research: Conceptual, strategic and statistical considerations. Journal of Personality and Social Psychology, 51, 1173-1182.

Chong, W. T. (2012). Critical success factors for small and medium enterprises: perceptions of entrepreneurs in urban Malaysia. Journal of Business and Policy Research, 7(4), 204-215.

Coles, J. L., Daniel, N. D., \& Naveen, L. (2014). Co-opted Boards. Review of Financial Studies. doi: 10.1093/rfs/hhu011

D’Angelo, A., Majocchi, A., \& Buck, T. (2016). External managers, family ownership and the scope of SME internationalization. Journal of World Business, 51(4), 534-547. doi: http://dx.doi.org/10.1016/j.jwb.2016.01.004

Essen, M. V., Oosterhout, J. H. V., \& Carney, M. (2012). Corporate Boards and the Performance of Asian Firms: A Meta-analysis. Asia Pacific Journal of Management, 29(4), 873-905. 
Forsman, H., \& Temel, S. (2011). INNOVATION AND BUSINESS PERFORMANCE IN SMALL ENTERPRISES: AN ENTERPRISE-LEVEL ANALYSIS. International Journal of Innovation Management, 15(03), 641-665. doi: doi:10.1142/S1363919611003258

Gunday, G., Ulusoy, G., Kilic, K., \& Alpkan, L. (2011). Effects of innovation types on firm performance. International Journal of Production Economics, 133(2), 662-676. doi: http://dx.doi.org/10.1016/j.ijpe.2011.05.014

Haji, A. A., \& Mubaraq, S. (2015). The implications of the revised code of corporate governance on firm performance: A longitudinal examination of Malaysian listed companies. Journal of Accounting in Emerging Economies, 5(3), 350380. doi: doi:10.1108/JAEE-11-2012-0048

Henning, K. (2013). Recommendations for implementing the strategic initiative INDUSTRIE 4.0.

Heugens, P. P., Essen, M. V., \& Oosterhout, J. H. V. (2009). Meta-analyzing Ownership Concentration and Firm Performance in Asia: Towards more fine-grained Understanding. Asia Pacific Journal of Management, 26(3), 481512.

Hilmi, M. F., Ramayah, T., Mustapha, Y., \& Pawanchik, S. (2010). Product and process innovativeness: evidence from Malaysian SMEs. European Journal of Social Sciences, 16(4), 556-564.

Hogeforster, M. (2014). Future Challenges for Innovations in SMEs in the Baltic Sea Region. Procedia - Social and Behavioral Sciences, 110, 241-250. doi: http://dx.doi.org/10.1016/j.sbspro.2013.12.867

Hult, G. T. M., Hurley, R. F., \& Knight, G. A. (2004). Innovativeness: Its antecedents and impact on business performance. $\quad$ Industrial Marketing Management, $\quad 33(5), \quad 429-438 . \quad$ doi: http://dx.doi.org/10.1016/j.indmarman.2003.08.015

INSEAD, Organization, W. I. P., \& University, C. (2017). "Global Innovation Index 2017" Innovation Feeding the World.

Jiménez-Jiménez, D., \& Sanz-Valle, R. (2011). Innovation, organizational learning, and performance. Journal of Business Research, 64(4), 408-417. doi: http://dx.doi.org/10.1016/j.jbusres.2010.09.010

Keskin, H. (2006). Market orientation, learning orientation, and innovation capabilities in SMEs: An extended model. European Journal of Innovation Management, 9(4), 396-417. doi: doi:10.1108/14601060610707849

Lasi, H., Fettke, P., Kemper, H.-G., Feld, T., \& Hoffmann, M. (2014). Industry 4.0. Business \& Information Systems Engineering, 6(4), 239-242.

Liao, Y., Deschamps, F., Loures, E. d. F. R., \& Ramos, L. F. P. (2017). Past, present and future of Industry 4.0-a systematic literature review and research agenda proposal. International Journal of Production Research, 55(12), 36093629.

Masso, J., Roolaht, T., \& Varblane, U. (2013). Foreign direct investment and innovation in Estonia. Baltic Journal of Management, 8(2), 231-248. doi: doi:10.1108/17465261311310036

Model, N. E. (2010). The new economic model for Malaysia concluding Part 2. National Economic Advisory Council. National SME Development Council. (2012 - 2020). SME Masterplan, Catalysing growth and income.

North, D., \& Smallbone, D. (2000). The Innovativeness and Growth of Rural SMEs During the 1990s. Regional Studies, 34(2), 145-157. doi: 10.1080/00343400050006069

OECD. (2005). Governance of Innovation Systems - Synthesis report. 1.

Otero- Neira, C., Lindman, M. T., \& Fernández, M. J. (2009). Innovation and performance in SME furniture industries: An international comparative case study. Marketing Intelligence \& Planning, 27(2), 216-232. doi: doi:10.1108/02634500910944995

Raoul, M., Pierluigi, M., \& Monica, P. (2012). Ownership Structure, Governance, and Innovation: Evidence from Italy. Government of the Italian Republic (Italy), Ministry of Economy and Finance, Department of the Treasury working paper, 10 .

Rjoub, H., Aga, M., Abu Alrub, A., \& Bein, M. (2017). Financial Reforms and Determinants of FDI: Evidence from Landlocked Countries in Sub-Saharan Africa. Economies, 5(1), 1.

Rosenbusch, N., Brinckmann, J., \& Bausch, A. (2011). Is innovation always beneficial? A meta-analysis of the relationship between innovation and performance in SMEs. Journal of Business Venturing, 26(4), 441-457. doi: http://dx.doi.org/10.1016/j.jbusvent.2009.12.002

Schmidt, R., Möhring, M., Härting, R.-C., Reichstein, C., Neumaier, P., \& Jozinović, P. (2015). Industry 4.0-potentials for creating smart products: empirical research results. Paper presented at the International Conference on Business Information Systems.

Schumpeter, J. A. (1934). The Theory Of Economic Development Harvard Uni. Press, Cambridge, MA.

SME Corporation Malaysia. (2015). SME Annual Report 2014-15.

Tan, K. S., Chong, S. C., Lin, B., \& Eze, U. C. (2009). Internet- based ICT adoption: evidence from Malaysian SMEs. Industrial Management \& Data Systems, 109(2), 224-244. doi: doi:10.1108/02635570910930118 
Tanganelli, D., \& Schaan, J.-L. (2011). Ownership Strategy in SMEs' International Joint Ventures. Journal of Small Business \& Entrepreneurship, 24(4), 551-566. doi: 10.1080/08276331.2011.10593553

Teixeira Latini, E., Rubens Fontes-Filho, J., \& L. Chambers, E. (2014). Private equity and corporate governance: managing Brazilian SMEs. Corporate Governance: The international journal of business in society, 14(2), $220-237$. doi: doi:10.1108/CG-02-2013-0017

Thompson, P., \& Zang, W. (2015). Foreign direct investment and the SME sector. International Journal of Entrepreneurial Behavior \& Research, 21(1), 50-75. doi: doi:10.1108/IJEBR-12-2013-0218

Ughetto, E. (2010). Assessing the contribution to innovation of private equity investors: A study on European buyouts. Research Policy, 39(1), 126-140.

Umrani, A. I., Johl, S. K., \& Ibrahim, M. Y. (2015). Corporate Governance Practices and Problems Faced by SMEs in Malaysia. Global Business and Management Research: An International Journal, 7(2).

Umrani, A. I., Johl, S. K., \& Ibrahim, M. Y. (2017). Ownership Structure Attributes, Outside Board Members and SMEs Firm Performance with Mediating Effect of Innovation in Malaysia. Global Business and Management Research, 9(1s), 393.

Westman, C., \& Thorgren, S. (2016). Partner Conflicts in International Joint Ventures: A Minority Owner Perspective. Journal of International Management, 22(2), 168-185. doi: http://dx.doi.org/10.1016/j.intman.2015.12.002

Zahra, S. A. (2010). Organizational learning and entrepreneurship in family firms: exploring the moderating effect of ownership and cohesion. Small Business Economics, 38(1), 51-65. doi: 10.1007/s11187-010-9266-7 